\title{
Translation and language and cultural policies: The importance of political cognizance in audiovisual translator training
}

\author{
A. Şirin Okyayuz ${ }^{\text {a }}$ (iD) \\ ${ }^{a}$ Bilkent University, Faculty of Humanities and Letters,Department of Translation and Interpreting, Ankara 06800, Turkey
}

\section{APA Citation:}

Okyayuz, A.Ş. (2019). Translation and Language and Cultural Policies: The Importance of Political Cognizance in Audiovisual Translator Training. Journal of Language and Linguistic Studies, 15(3), 937-952.

Submission Date:24/03/2019

Acceptance Date:27/07/2019

\begin{abstract}
Policies concerning language and culture are integral to the translators' work as they are an intrinsic part of the translation process. Thus, it becomes necessary to include a good bit of what could be referred to as 'policy cognizance', which could be defined as an understanding of the policies that mold the practice spanning from historical perspectives to the present day laws and regulations, in translator training. The following study is an effort to refer to some of the subjects that may be included in an audiovisual translation course within the objective defined. It aims to exemplify and justify the integration of certain training modules that need to be included in a comprehensive training curriculum if the translator-to-be is to become policy cognizant in the field. Following an overview on the relation between state, language policy and translation, the study goes on to concentrate on suggestions for modules that can be integrated into audiovisual translation training at university level. It is penned with the hope of providing food for thought and a perspective for the translator trainer and translator-to be who wish to specialize in audiovisual translation.
\end{abstract}

(C) 2019 JLLS and the Authors - Published by JLLS.

Keywords: audiovisual translation training; politics of language; language and culture policies; translation; soft power

\section{Introduction}

A translator is a professional who in the broadest sense of the word transfers texts from one culture and language to another and makes these available for the target audience, receivers etc. and in doing so (recreating the text), enables the building of communicative bridges across language and cultural boundaries. The act of translation encompasses not only (in a linguistic sense) stating what has been produced in one language in another, but enabling the communicative transfer of what has been produced in a certain language and culture into another. This necessitates many skills and a broad understanding of many fields. In this sense, translators, by virtue of their profession, are always in a sense 'multidisciplinary' (in that they have to have a broad knowledge of many disciplines- not only the fields that they translate, but also the fields that affect translation practices). They also consider the

\footnotetext{
* Corresponding author. Tel.: +0-90 5323661288

E-mail address: yener@bilkent.edu.tr
} 
politics of a text, the content, the intent, the reception, the specific field of expertise etc. They work with specific terminologies, differing discourses, various text types and are able to deconstruct original texts and reconstruct them for the end-users of a translation. This process necessitates consideration of multiple facts (some of which overlap, some of which clash across language and cultures) and so much more.

Policies and realities in a country are also probably one of the most prominent components that affect the above summarized work of a translator. Policies concerning language and culture are integral to the translators' habitus (for a wider understanding of the notion see Bourdieu, 1983, 1991, 1992; Gouanvic, 2005; Simeoni, 1998) and thus are an intrinsic part of the translation process. Initially translators need to know the realities of the societies they are serving; but more importantly they need to have a full understanding of the receivers (i.e. readers, viewers) in order to fashion the product (i.e. translation) in line with its reception through said realities. Translation has long served as a tool and means for certain political and social realities in many countries and the example of Turkey is no different. The translation of foreign legal codes in drafting of the initial laws of the Republic of Turkey (Altay, 2002); foreign AV products dubbed and adapted between 1920-1970 to establish a local cinema (Scognamillo, 2014); the translation of foreign AV products for the TRT (Turkish National Radio and Television) from the late 1960's onwards (Çankaya, 1992); the translation and appropriation of literary genres and specific works for the enrichment of the local literary repertoire (Anamur, 1997; Paker, 2002); translations leading to the birth of certain genres like children's literature (Neydim, 2003, Okyayuz, 2017) and many other such examples may be provided to exemplify the extent of this practice.

Taking this line of reasoning a step further, it becomes necessary to include a good bit of what could be referred to as 'policy cognizance', (which could be defined as an understanding of the policies that mold the practice spanning from historical perspectives to the present day laws and regulations), in translator training. This would mean acquainting the translator-to-be with not only simple policies (i.e. like how to censor the translation of a film if that is the case in the country in question), but also policies and ideologies prevalent in the culture they are to serve. In considering that translation is a two faceted endeavor (in that there is an original and a translated text) one could argue that this training needs to encompass all of the translators working languages and their cultures. Furthermore, one could posit that this would be integral to any branch of translation and its training. In many cases such a module or seminars designed to serve this objective are included in translator training; but, with newer fields of translation being integrated into courses taught at university level either due to advances in technology (i.e. live subtitling), developments in a country (i.e. government supported accessibility to media) or changes in the tools used for translation (i.e. the use of different CAT-computer assisted translation programs- for localization) trainers are usually the first to map out what needs to be included in the theory and policy cognizance modules of these courses. There are usually few prior examples and many institutions will be concentrating on applied translation studies when they initially design a course. Nevertheless, at some juncture it becomes necessary for this to evolve to provide the translators-to-be with a wider understanding required at university level training.

One of the newest branches of translation training that has received attention from trainers and practitioners in Turkey has been audiovisual translation (AVT). AVT can be broadly defined as the translation of audiovisual products (film, series, commercials, news, shows etc.) so that globalized and popular products, news and information are transferred around the world. Translation practices include subtitling, dubbing, surtitling, voice-over and many others. It also includes translation for media accessibility purposes, such as audio description for the blind and visually impaired and subtitling for the D/deaf and hard of hearing or sign language interpreting for the D/deaf. Furthermore, recent trends also include remakes (the locally produced versions of audiovisual products such as the remaking of a famous TV series with local actors and in a local setting), adaptations, format remakes (i.e. The Voice 
transposed in the Turkish as $O$ Ses Türkiye) and other products within the scope of audiovisual translation (for a broader explanation of the scope of AVT see Okyayuz \& Kaya, 2017). Turkey has a long tradition of AVT and boasts of continually increasing AVT opportunities (both in and ex-translation -translation into Turkish and from Turkish into foreign languages) for young translators (for history of Turkish AVT see Okyayuz, 2017b). Unlike other fields of translation (i.e. literary translation, translation of legal texts), which have been diligently studied by Turkish translation scholars, AVT remains one of those fields in which current research does not seem to meet the training needs (as stated above) of a booming field.

As previously stated, any type of translator training needs to include a good amount of knowledge about the policies that surround the production process as well as country specific facts to fashion the product.

Since there are several comprehensive volumes on training the audiovisual translator by colleagues from other countries (see: Diaz-Cintas, 2008 for a comprehensive compilation of resources) one could ponder why the above mentioned resources could not be integrated into AVT training in Turkey. Such a straightforward approach is not as effective or even as wise as one would presume. For example, whereas research on censorship and such policies in other cultures could be integrated into a Turkish training curriculum, these would only provide the translator-to-be with an understanding of the concept (i.e. censorship) and the realization that 'this is a reality in some parts of the world', thus a part of the job. But, a professional needs to be cognizant of what the actual practice is in their own country and furthermore has to develop an understanding about why this is so to be able to implement such a policy in the work in question. Thus, generalist resources provide an understanding of concept and universal realities, but not details on 'what goes' for a certain country.

Secondly and more importantly, the audiovisual sector in each country is fashioned according to the realities of the receivers and the policies surrounding it. It would not be wrong to state that each case is country/language specific (sometimes even region specific). So a comprehensive training would require specific examples and study. Furthermore, in order to understand such policies and internalize these to the extent that they are reflected into the translation process, the translator needs to access the research of experts from other fields (i.e. sociolinguistics, politics, sociology) and if possible form an informed opinion, habitus and conclusion of what this would mean for the translation to be undertaken. The data for the formulation of such a backdrop needs to be country specific.

Another facet of translation training that needs to be considered at this juncture is the importance of teaching translation history and theory in any field of translation. A good bit of historical insight allows translators to gain a larger view of the field in which they practice, as theory allows for grounding in the field. Thus, a further enlargement of the training module is required; one that includes how policies and realities of a county affected the translation sector in question (in this case AVT in Turkey).

The following study is an effort to at least refer to some of the subjects that may be included within the objective defined. Furthermore it sets out to exemplify and justify the integration of certain training modules that need to be included in a comprehensive audiovisual translation training curriculum (in Turkey) if the translator-to-be is to become policy cognizant in the field. Following an overview on the relation between state, language policy and translation, the study goes on to specifically concentrate on suggestions for seminars that can be integrated into AVT training at university level to integrate professional AV translators into the market. It is penned with the hope of providing food for thought and a perspective for the translator trainer and translator-to be who wish to specialize in AVT or its training. 


\section{A brief overview of the relation between state, language policy, media and translation}

Since the 19th century language issues in society have been politicized so much so that it seems that friction around language and the issues that surround it are a fairly common feature and examples abound (Núñez, 2016, p.1). It is clear that many of these issues are inexorably intertwined with translation. The issues can be explored within the context of language rights (Freeland \& Patrick, 2004, p.5) which are also part of the policies of supranational entities like the EU or the United Nations (Extra \& Gorter, 2008, p.38, p.42). Beginning from the 18th century, the rise of a type of state in which centralized government strongly identified the cultural identity of the dominant nation (McDermott, 2011 , p. 1) led to the notion of nationality became linked with the state and language began to be seen as element of nationality (Hobsbawn, 2000, pp.21-22), and furthermore it became central to the modern definition of nationality (Hobsbawn, 2000, p.59).

It was at this juncture that language management (policy) emerged as a means to mobilize national identity (Spolsky, 2009, p.152). Cited as one of the staunchest pillars of national identity, language (Ruzza, 2002, p.168) is viewed as a prerequisite for the survival of a culture (Plewa, 2002, p.183). This is the case for many nations, as for example Barbour (2002, p.166) working on the dissemination of German in Europe and national identities, Judge (2002, p.46) studying the unity and cultural legacy achieved through the use of a single language, Vikor (2002, p.105) researching the idea that the use of different languages in Finland, Sweden, Denmark, Norway and Iceland lay at the foundation of the establishment of separate identities, all agree on the importance of the use of language as a tool for political purposes. Such is also inevitably the situation in Turkey.

The founder of modern Turkey, Mustafa Kemal Atatürk, referred to language and culture in very much the same vein in his famous speech and his definition of culture and language designate both as evolving modern powers (Göktürk, 1981, p. 27), which necessitate the use of an equally modern tool which is language policy. Language facilitates the formulation and the perseverance of a culture (the sum of the attributes and experiences of a society) and is the capital which enables these (Börekçi, 2006, p.16). Furthermore, it has been noted that Atatürk viewed the use of Turkish as a tool for the Turkification of a newly established nation (Sadoğlu, 2003, p. 214). Language and cultural reforms were previously used during the Ottoman era for the modernization of the state and this legacy continued after the establishment of the Republic (Altındağ, 2016, p.46). Turning their back on the remnants of a predominantly Eastern empire (Tuna, 1991, p.62) ideas and works from the West were expressed though translation and literature and the Turkification of the language of said literature also marked a step in this direction (Kili, 1981, p.178; Y1ldı, 2001, p.16).

Following this ideology the entrée of mass media in Turkey, especially television in the latter half of the 20th century, marked the need to situate this medium in terms of how it would effect and intersect with language, culture and translation policies dating back to the establishment of the Republic. In her research on the AVT in Turkey Okyayuz (2017b, p.115) states: The discussion of issues such as the use of different types of AVT for specific purposes (i.e. localized adaptations of foreign AV products for building a national identity, dubbing with the standard dialect to support language standardization and learning, providing information flow and familiarity with foreign cultures through subtitling), social and political policies that influence AVT (i.e. tax reductions in films imports, foreign/domestic productions, audience viewing rates, censorship organs), power play (i.e. state led AV sector, elitist, ideological, and populist AV productions and translations), actors (i.e. governments, foreign firms and agreements) and technologies (i.e. dubbing, subtitling) are all of interest to the AVT researcher. Following the trajectory of the audiovisual sector and AVT in Turkey, there is evidence to suggest different types of AVT, in line with the realities of certain eras, may be used in line with social and political aspirations. 
Information sector companies and governments have touted their activities as the key to the planets economic and cultural future and even a solution to its problems, thus allocating to media an immensely large role within societies (Noam, 2016, p.4). Nye (2017) identifies media and the culture and language that is integral to it as one of the greatest soft powers (the power to convince and attract) in the modern day world.

In the same vein, Öztürk (2004, p.97) states that, research in Turkey on the subject is conclusive on the point that, due to the fact that it uses both the visual and audial channels television has a compelling and paramount effect on the viewers in Turkey. This power was not yielded to anyone but the state, as following the establishment of the state owned TRT (Turkish National Radio-Television) in 1968, up to 1990 the state monopoly over the masses was broken only by the channel Star 1 and this was followed in 1994 by the legalization of the establishment of private channels which still flourish today (Öztürk, 2004, p.97).

Without going into detail, one could state that researchers in the field are of the opinion that generally language but also art, culture and educational policies throughout the history of the Republic have not been realized/instigated based on their own dynamics and the rational interest of the state, but the norms and sense of identity of the ruling parties of each period (Uçar, 2017, p.24). This alone goes to show the extent of the power they exert over a society and nation. The general consensus among experts was that mediums such as radio and television which are organs that not only serve society, but are influential in coloring the perspectives of viewers in terms of issues such as politics, news, education, religion, science, sports etc. have to be carefully molded to integrate the best language (translation) policy possible (Güllüdağ, 2012, p.50). The entwined origin and nature of language and national identity building and thus translation are central pillars of policy (Orhan, 2017, p.332). The speed with which such technological mediums can influence language and its use (Karahan, 1999, p.53) is due to many factors but mostly to the fact that surveys in the country clearly indicate that especially the TV is probably the most widespread common platform in which language dominates: Reading magazines \% 4 , Reading books $\% 4,5$, Reading newspapers $\% 22$, Listening to the radio $\% 25$, Watching television \%94 (Savaş, 2002 p.354).

Research on the impact of the language used on television series in Turkey on the society reveals the approximately $49 \%$ of viewers state that they tend to use words and phrases they hear from characters on these programs more frequently in their daily lives; this is one of the clear indicators on how language on TV affects language in the society (Kurt, 2011, p.193). Many studies are conducted on the subject in Turkey for example dealing with the effects of translationese (foreign words that become frequent in language due to stilted translations) (Aksan, 2001, p.198; Erdem 2002; Lewis 1999, p. 138; Hepçilingirler, 1999, p.93). Furthermore, according to experts, taking into consideration the interconnectedness of the media, language and communication (Özerkan, 2012) these necessarily influence viewers not only on the basis of the language that is used, but also through the choice of programs and the translation types and strategies used to disseminate foreign products. Another effect that ensues from society embracing medium such as TV on a grand scale in this age of informationcommunication, is the change it brings to society itself (Özçağlayan, 1998, p. 24-25). For example, countless studies reveal that content from TV programs has had a major influence in relaying differing cultural values, lifestyles to Turkish audiences (Pazarbaş1, 2016, p.171). Other studies reveal that starting from the 1970's television and audiovisual media became the major tool in setting the rhythm of life (Tunç, 2005, p. 89). Furthermore, advances such as these also lead to a web based viewing trend and user friendly applications which facilitate social interaction (Taşdelen \& Kesim, 2014).

In light of these facts it is clear that when translating for this medium the translator has to be cognizant of not only the 'power and influence' the product has over the target (receiving) society, but also how it is to be molded to be received as a product within that society, and furthermore why it is to go through 
the process that is necessary. Translators do not work in a vacuum they work to produce products that are fashioned from the smallest unit (i.e. the censoring of socially unacceptable words), to the largest unit (i.e. making films accessible to the blind) in line with the norms, realities and maybe more importantly the policies prevalent in a society. This brings us back to the initial point about policy (both historic and current day) cognizance that is an integral part of audiovisual translator training.

\section{Suggestions for the types of modules to be included in audiovisual translator training and module design}

The implications of including such modules in AVT training are also important considerations. Should such modules be included in the relevant AVT courses primarily it becomes clear that the translator will acquire a larger perspective of the actual impact of the work at hand (i.e. how the translated products effect or influence societal conception); this would in turn lead to more educated and carefully considered translators choices. A second implication would be that the translator would make more conscious choices as regards the actual reflection of such policy in the translation process (i.e. foreignizing certain elements for acquaintance with a culture or domestication when the state policy calls for cultural preservation). A third implication would be the mainstreaming of translated products by the translator in line with prevalent (policy oriented) norms thus fulfilling one of the facets of the use of the translated product (i.e. the aim of the translation). A fourth implication would entail the translator's increased sensitivity to the habitus of colleagues in the time and place in which they (all translators working in the same field in the same language combination etc.) design their translations. This would then lead to the sharing of experience and knowledge, not only on the policy of translation front but also in terms of the actual richness and variety of translator's options and choices. A fifth implication would be the provision of a historical perspective on the evolving nature of translation studies and the act of translation itself. For example understanding ideas underpinning previous translations and projecting how successful certain approaches were in the past to formulate strategies for the present. There are of course multiple further implications to the addition of such modules into the course which would be too long to list in the scope of a short paper; but suffice it to say that implications would be various and almost all would a be added benefits to the multidisciplinarity and richness of translator training.

Before the below exemplified suggestions are to be considered by the trainers there are certain parameters that must also be taken into account.

As with every course, the type of AVT taught within a course or in a curriculum (i.e. subtitling, dubbing) will affect the choice of the trainer in what to include in the training. Furthermore, training content will also be tailored to include or discard certain subjects according to the aim of the course (i.e. including accessibility seminars when subtitling for the D/deaf and hard of hearing is taught or where the curriculum does not include translation for accessibility seminars concerning this type of translation will become unnecessary). So, the suggestions provided in this section are just that.

Furthermore each trainer must decide about how to include a subject in the training. Some options that immediately spring to mind are seminars by the trainer, seminars by experts who are called in as visiting speakers, research and presentations by the students, intertwining facts with practice as in providing information and background as the students translate etc.

Another decision of importance is the duration. Initially the duration will depend on the length and number of courses on a specific subject. For example, if the students have three courses on subtitling there would be time to provide a number of different modules for policy cognizance, whereas the length and number of modules to be included in a single semester course would be much less. The duration of 
the module provided would also need to be determined on the basis of the orientation of the training institution in question. For example, in two universities which have translation and interpreting departments in Ankara, one tends to concentrate more on market practice and preparing the students for entrée into to the market upon graduation, whereas the other prefers to view undergraduate training as a basis or a start and propels students to and prepares them for graduate training in specialized fields of translation.

Also the sheer number of issues and subjects that can be included in such modules (i.e. everything from laws and regulations to research about language learning through AVT) is expansive. It is important for the trainer to limit the number and content. Below are some examples that may provide food for thought for the trainer of an AVT course in line with the content and intent of the course in question.

\subsection{Including a historical perspective in the course with reference to policy making}

A good bit of history to be included in any translation course provides the translator-to-be with insight on several issues. For example, a short history of AVT in Turkey provides answers to questions regarding not only how, but why the sector in question evolved in the manner that it did. This in turn enables the initiate to primarily internalize rationale behind practices, secondly to predict professional practices in the future, thirdly to understand the scope of AVT practices in a country (both past and present) and so much more.

AVT practices in a country need to evaluated and considered within the realities in which they flourished and not with a retrospective view. For example, Okyayuz (2017b, p.117) explains the use of foreign AV at the birth of the Turkish cinema and AVT as follows: [...] studies in Turkey underline that, in the 20th century, cinema and television have contributed to the evolution of Turkish society in a way as to both retain the Turkish identity and also to cultivate it in a certain direction (Aziz 1991, 5). Since the late 1950s cinemas in major cities and the outdoor cinemas set up in small towns and villages alike where used in Turkey to provide the Turkish people with an image of the West they were striving to become a part of. The sounds and images portrayed through this medium would allow the Turkish people to acquaint themselves with the culture of the West, everything from the style of dress, to the music, to the lifestyles and so on. Built on the remnants of a Muslim Empire, the young, impoverished nation had a vision of Westernization with AVT providing a tangible example of this for the masses who had had no historical contact, commonality or shared culture with the West in the sense that Europe or America had (see Tatlı 2015 for full scale study of Turkey's Westernization project through the use of AV and AVT).

Experts in media, politics, sociology, and communication studies have been reporting on the importance of AV products and AVT for the cultivation of Turkish society for over half a century (see: Gül ,2009; Kejanlığlu, 2001; Oskay, 1971; Mete, 1992). These tie in with the role of translation within a society, and the present day repertoire (both old and new) of translated AV products which are also very important in analyzing the formulation and importance of AVT in a given country. Furthermore, the impact of television and cinema on the cultural, societal, political and other realities has left researchers unanimously agreeing on the power of AV products and AVT in Turkey (see: Batmaz, 1995, p.3; Aziz, 1991).

Thus, it would be wise to include a module in AVT training which maps the emergence of the field and the evolution to the present day. This is just a suggestion for the design of a module; but if such a module were to be included in the training it should include several time periods. The first period would be the emergence of AVT with the establishment of the first movie theatre in 1914 up to the 1950's, which could be referred to as the era that marks the beginning of AVT, and the prevalent types of AVT 
include replacement and translation of intertitles in the silent movie era followed by the Turkified dubbing of films with the advent of the talkies, followed by the mainstream adaptations of foreign films that were to give rise to the local AV sector. The second period which spans from 1960s to 1983 when the dominance of translations and adaptations from the West had never reached the heights it did previously (Scognamillo, 2014, p.117). The Turkish cinema moved into a new era and it was becoming an industry. From 1968 onwards television also gained dominance with the establishment of the TRT. Television initiated cultural transfer through dubbing in the 1969-1983 period with the establishment of a state owned and run television. Okyayuz (2017b, p.127) states: Television marked the entrance of the rest of the world into the lives of a majority of the Turkish people, especially those living in rural areas. This mass mediation of AV translated products was handled in a way as to allow a smooth passage of the 'other' into the lives of the target viewers. In line with the norms of the society, showing sensitivity where national issues were at stake and keeping in mind that Turkish families watched television together, translated AV products were mediated in a manner as to make them acceptable for family consumption, make them examples of correct behavior for the society at large and make them appealing to the public.

Whereas one cannot prove exactly what factors played a role, or whether political and social ideologies played the central role in intentionally embracing adaptation and dubbing as the dominant type of AVT at the time exemplified in the study, the fact remains that they were used and the advantages they gave the mediator to manipulate the AV product 'in translation' were put to full use in Turkey's case.

A third period would be the rise of private televisions between 1983-2000 which with the opening up of the economy to foreign sectors, actors and investment (Kongar, 2013, p.220) and the ongoing struggle of the Turkish nation to unlearn and undo the homogenous, monolithic and absolute ideology adopted by the state's mentality and imposed on the people for the sake of modernization and westernization (Karanfil, 2006, p.72), led to a large scale revolution and evolution of the AVT sector in Turkey. The initial change came with the switch from dubbing to subtitling in movie theaters (Gül, 2009, p.83); an increase in the number of movie theaters and the number and variety of foreign films (Gül, 2009, p.83); an explosion of private television channels some of which also used subtitling to advocate global integration and because of financial concerns (Mete, 1992); an increase in paid TV platforms and digital platforms and videos (Tamer, 1983, p.134); the establishment of a state guided censorship organization due to the inability to control the inflow of the type of AV translated products which were deemed to be negatively affecting the Turkish morals and identity (for the establishment of the two central organs Radyo Televisyon Yüksek Kurulu (RTYK) November 1983 and Radyo ve Televizyon Üst Kurulu (RTÜK) 1994 see Kejanlığlu, 2001, pp110-113); and new laws on media and cinema which brought copyright concerns cutting out adaptations and bringing on legal remakes (for details see Law numbered 3257 enacted on 23/1/1986 on Copyright in Cinema, Video and Music) (see Okyayuz, 2017b, pp.127-128 for details). This is followed by a fourth period for AVT in Turkey from the millennium onwards saw the rise of other phenomena that Okyayuz (2017b, pp.129-130) describes as follows: $[\ldots]$ the use of the Internet to disseminate AV products and the rise in the social translation sector (Okyayuz 2016a); the advent other technologies such as DVD and diverse subtitling practices (Okyayuz 2016b); as opposed to the 1990s, the heavy censorship of AVT products and the politization of dubbing practices for conservative audiences; the advent of remakes on a large scale (Findik \& Okyayuz 2013), the first examples of which were faithful translations, but which evolved into freer remakes aligning itself not with the original work but with contemporary Turkish conservative norms (Okyayuz 2016c); and a revival of a contemporary Turkish cinema and television with its own rich repertoire and extranslation of Turkish series and films (Okyayuz 2016d). 
The details of the module suggested above would need to be detailed by the trainer in line with the student profiles knowledge of Turkish history and the scope of their general knowledge.

\subsection{Including a perspective on current policy in the country}

A further perspective that may be included in any AVT course would be the current policies that are enacted and embraced, or at least supported by the national organs. Of course one obvious track to take in this module would be to refer to official publications or the work of state related organs on AVT.

In January of 2019, followed by a workshop comprised of sessions on different types of accessibility to media services and attended by government officials, media representatives, NGO's for individuals with disabilities and academics, the Turkish Radio and Television Supreme Council (RTÜK) drafted a final declaration on the improvements to accessibility practices for media services. In preparation for a regulation on the matter and in line with Article 37 of the 6112 numbered Law of the Supreme Council enacted in 2011 and section 1.5.4 of the 2016-2020 National Strategic Plan and following the 21/06/2018 dated meeting and decisions by the Supreme Council the workshop aimed to improve accessibility to media services for the blind, visually impaired, D/deaf and hard of hearing. This development was preceded and based on the previous steps taken for example the survey on television watching/following rates conducted in 2007, the signing of the United Nations Convention of the Rights of Persons with Disabilities in 2008, the 6112 numbered national Law which stated the importance of providing access and facility to persons with disabilities as regards information and media services, the 2011 dated regulation concerning changes to media rules and procedures. (see: RTÜK, 2018 for details)

Such developments and national policies have to be followed by the translators-to-be if they are to plan their careers and furthermore understand the tendencies that are prevalent in a country at a given time. Such a module would also necessitate the in-class viewing of accessible versions of products and maybe even comparisons of accessible versions in the students working languages to exemplify the differences in translation trends and strategies across cultures.

\subsection{Including a perspective on the use of AVT as soft power and ex-AVT}

The use of AVT as soft power and the sheer volume of ex-AVT are also worth attention in the AVT classroom as this will allow future professionals to visualize possible translation directions (from Turkish into foreign languages) and work opportunities (i.e. working for international subtitling companies). Also in addition to this the social and political realities linked to AVT and the politics of AVT are very apparent in ex-AVT in Turkey. In her research on the impact of translated Turkish AV products Okyayuz (2017c) cites many examples of the use of AVT as soft power and goes on to map some of the social, political and other impacts of the translation of Turkish series into other languages.

Okyayuz (2017c, p.683) concludes that even though it is difficult to map out the actual role of the translation of cultural items and the influences they hold over societies, diplomacy, culture, politics, religious conservatism and the like, experts in the field like Çevik (2014) state that "both high culture and popular culture products are equally soft power resources." As translators are one of the major actors in the production of AVT products which are internalized by the viewers they should be cognizant of these products affecting changes big and small, as well as drawing many reactions and causing controversies. According to the researchers compilation of research from other fields, "a Turkish soap opera influences divorce rates in the Middle East, a series about an Ottoman sultans' harem coming at the right time in history and political conjuncture allows people to rediscover commonalities in a region, the drama of a single mother raising a child with leukemia on her own bridges gaps between the Atlantic and Mediterranean, a victim of rape portrayed in a social tragedy allows people around the world to rethink women's issues" (Okyayuz, 2017c, p.683) and the list is long. On the other hand, the facts are 
clear, audiovisual translations allow the translator to become a major actor in the front trenches of international communication with the masses.

Some translation scholars like Dick (2012, p.9) underline the importance of works in translation studies that underline the role of translations - or translated products in this case- in transmitting cultural ideas across borders and languages.

Thus, it is clear that: "In the current media scenario, there is an on-going transfer of power- from the media owners to the distributors and professionals who manipulate (literally speaking) the multiple codes. Translators are a part of this new group but do not yet realize what this implies or recognize its full effects." (Gambier, 2006, p. 2).

Such a training module would need to include an in-class viewing of ex-translated Turkish products and an analysis of the possible implications of the translators' choices in such work.

\section{Conclusions}

When referring to language and cultural policies and translation, and especially AVT there are many subjects which could be included in a training curriculum. Some suggestions for training modules are:

- Censorship and the specific laws and practices;

- The underpinning of national identity through the promotion of the standard language (the country's designated national language) use on media;

- The selection of translated audiovisual material to be shown on media in accordance with viewer preferences and reception studies;

- Supporting dubbing and/or subtitling for certain political purposes or in line with certain societal realities;

- Accessible media policies and how these need to be fashioned in line with prevailing realities, and receivers profiles;

- The use of media to acquaint a culture with that which is foreign (both in the case of in and extranslation);

- History of AVT and the politics behind its evolution;

- Mapping the background/profiles of the audiences/receivers in line with educational and cultural policies to fashion products that are accessible and acceptable for end-users;

- The use of censorship and media orientations/trends;

- Mapping the effects of ex-translation as a soft power for Turkey;

- The use of subtitling practices for learning Turkish and acquainting migrants with the mother tongue and culture of the country;

The artistic, societal, linguistic and cultural limitations and the opportunities presented by the use of certain types of AVT (this point ties in with the ideas aptly summarized by Gottlieb (2005, p.13), where he explains that certain types of AVT lead to different impacts on target audiences. He analyses different types of production across factors such as affordability, semiotic authenticity, dialogue authenticity, content mediation, access to original, foreign culture mediation, foreign language training, literacy training, domestic language boosting, linguistic integrity) and so on and so forth. A multifaceted view on each of these subheadings and many others would provide a valuable perspective for the translator. But, all of that research would be impossible to map within a single paper, since realities are always evolving and changing. But, a perspective still needs to be provided to the translator-to-be. The examples 
provided within the scope of this paper do not comprise an exhaustive list of the possible training seminars, but the subjects are chosen to present examples on different aspects.

Possible suggestions may be made for the design of courses, but as stated above each institution will be limited by its own realities so a one-size-fits-all course design is not likely. On the other hand a wise precaution may be to include policy cognizance modules and then to provide examples from actual translation in class. For example, a product that requires censoring in translation may be presented to the class after the module on censorship. One other suggestion could be to allow students to internalize such modules through research on receivers. For example, students could be asked to conduct interviews with the generation who were born in the 1960s, 1970s to ask them about the types of programs broadcast in Turkey during their childhood (in the years TRT was the only channel in Turkey) and their translations; student could be asked to research 'how this effected the receivers'. A further suggestion could be made to call in experts from other fields such as media studies to give seminars on the current policies surrounding broadcasting and provide information on the background of said policies. For example, an accessibility expert could explain why Turkey has currently undertaken the task of providing accessible media on various platforms with reference to the UN Convention (2008) and internal legislation on the subject mentioned above; this would also allow students to understand the multifaceted and multidisciplinary nature of the field. A multitude of suggestions such as the ones made above spring to mind; but it falls to the trainers to decide in accordance with their course flow just what is possible and feasible and what is not. Thus, each course design will present an example of a model which (hopefully) through time and the shared experience of trainers evolve to become relatively standardized training practices in major translation departments in Turkey.

It has become clear that given the sheer number and the speed with which AV products are translated for audiences in Turkey (and Turkish AV for foreign audiences), the work in question is prevalent in the lives of millions of people who have access to these products. Suffice it to say the impact of AV products in people's lives has been irrevocably underlined by field experts, but not so for the impact of the translation or the translator on these products. It is clear that with the initiation of AVT training at university level, these training modules or courses have to be designed beyond something that would be sufficient for a certificate course such as outlining types of AVT, training on the use of technology for subtitling etc. to include a cognizance of what the work at hand really entails. Translation scholars abroad have realized that, "in this changing mediascape, the translators have and will have a major role, if they fully realize their social-cultural function," (Gambier, 2006, p.7), now it is time for Turkish researchers to conduct the necessary research and for trainers to integrate these into courses or training in AVT. The specifics of the course design will depend on multiple factors such as the aim, scope, duration and content description of the course in question; the training policy (trend) of the department where the course is given; the insight of the trainer; the technological infrastructure at the institution; the presence (or lack) of experts, practitioners from related fields within reach and so on. But the bottom line is each trainer will have to map out modules and furthermore share these through research and writing with colleagues to formulate, integrate and develop the best practices in translation departments across Turkey in this new and ever-changing field of study.

\section{References}

Aksan, D. (2001). Türkçenin Gücü. İstanbul: Bilge Yayınevi.

Altay, A. (2002). Hukuk Dili ve Hukuk Çevirisi. Ankara: Evin Yayınları. 
Altındağ, N. (2016). Türk milliyetçiliğinin siyasallaşması ve bat1/batılılaşma algısı. AÇÜ Uluslararası Sosyal Bilimler Dergisi, 2(2), 43-64.

Anamur, H. (Ed.). (1997). Hasan-Âli Yücel anma kitabı: çeviri, ekinler ve zamanlar kavşağı. Istanbul: Yıldız Teknik Üniversitesi, UNESCO Türkiye Milli Komisyonu Yayını.

Aziz, A. (1991). Televizyon yayınlarında geleneksel kültür. Ankara: Türkiye Sosyal Ekonomik Siyasal Araştırma Vakfı Yayını.

Barbour, S. (2002). Germany, Austria, Switzerland, Luxembourg: The Total Coincidence of Nation and Speech Communities? In S. Barbour \& C. Carmicheal (Ed.) Language and Nationalism (pp.151-167). Oxford: Oxford University Press.

Batmaz, V. (1995). T.C. Başbakanlık Aile Araştırma Kurumu - Türkiye'de televizyon ve aile. Ankara: Bizim Büro Basımevi.

Bourdieu, P. (1983). The field of cultural production, or the economic world reversed. (R. Nice, Trans). Poetics, 12 (4-5), 311-356.

Bourdieu, P. (1991). Language and symbolic power. (G. Raymond \& M. Adamson, Trans). Cambridge: Polity Press.

Bourdieu, P. \& Wacquant, L. J.D. (1992). An invitation to reflexive sociology. Chicago: The University of Chicago Press.

Börekçi, M. (2006). Atatürk - Dil ve Kültür. A. Ü. Türkiyat Araştırmaları Enstitüsü Dergisi 31, 1521.

Çankaya, Ö. (1992). Türk televizyonunun program yapısı. İstanbul: Mozaik Basım ve Yayıncılık.

Çevik, S. (2014). Turkish soap opera diplomacy: A western project by a Muslim source. Exchange Journal of Public Diplomacy, 2014 (5), 77-102.

Díaz-Cintas, J. (Ed.) (2008). The didactics of audiovisual translation. Amsterdam: John Benjamins Publishing Co.

Erdem, S.D. (2002). The influence of English on Turkish: Lexical borrowing. Unpublished graduate thesis. University of East Anglia, Norwich.

Extra, G. \& Durk G. (2008). The constellation of languages in Europe: An inclusive approach. In G. Extra \& G. Durk (Ed.) Multilingual Europe: Facts and policies (pp. 3-60). Berlin: Mouton de Gruyter. doi:10.1515/9783110208351.1.3.

Freeland, J. \& D. Patrick. (2004). Language rights and language survival: Sociolinguistic and sociocultural perspectives. In J. Freeland \& D. Patrick (Ed.) Language rights and language survival (pp. 1-35). Manchester: St. Jerome.

Gambier, Y. (2006). Multimodality and audiovisual translation. Proceedings of the Marie Curie Euroconferences MuTra: Audiovisual translation scenarios, Copenhagen, May 1-5.

Gouanvic, M. (2005). A Bourdieusian theory of translation. The Translator, 11(2), 147-163

Göktürk, A. (1981). Atatürk'ün kültür tanımına yorumbilimsel bir yaklaşım. Dilbilim Linguistique VIİstanbul Üniversitesi. Yabancı Diller Yüksek Okulu Fransızca Bölümü Dergisi.

Gül, G. (2009). Sinema devlet ilişkisi: Dünyadan örnekler ve Türkiye. T.C Kültür ve Turizm Bakanlığı, Araştırma ve Eğitim Genel Müdürlüğü, IV Dönem Uzmanlık Tezleri. Retrieved on March 2019 from http://aregem.kulturturizm.gov.tr/Eklenti/31141, gulhanimgulpdf.pdf?0. 
Güllüdağ, N. (2012). Yazılı ve görsel basında dil estetiği. 21. Yüzyılda Eğitim ve Toplum, 1 (1) Bahar, 49-58.

Hepçilingirler, F. (1999). Dedim: 'Ah'! İstanbul: Remzi Kitabevi.

Hobsbawm, E.J. (2000). Nations and nationalism since 1780: Programme, myth, reality, (2nd ed.).Cambridge: Cambridge University.

İlaslan, S. (2014). Türkiye'de televizyon yayıncılığının kuruluşu: TRT ve kamu hizmeti yayıncılığı etrafındaki mücadeleler 1960-1980. Karadeniz Teknik Üniversitesi İletişim Araştırmaları Dergisi, $32-55$.

Inghilleri, M. (2003). Habitus, field and discourse: Interpreting as a socially situated activity. Target, $15(2), 243-268$.

Judge, A. (2002). France: One state, one nation, one language? In S. Barbour \& C. Carmicheal (Ed.) Language and Nationalism, (pp.44-82). Oxford: Oxford University Press.

Karahan, L. (1999) Radyo ve televizyon yayınlarında yöresel söyleyiş sorunu, Radyo ve Televizyon Yayınlarında Türk Dilinin Kullanımı- Tebliğler (25-26 Kasım 1998-Ankara), 53-57.

Karanfil, G. (2006). Becoming undone: Contesting nationalism in contemporary Turkish cinema. National Identities, 8:1, 61-75. DOI: 10.1080/14608940600571313.

Kejanlığlu, B. D. (2001). Yayıncılıkta düzenleyici kurullar ve RTÜK. In B.D. Kejanlığlu et al (Ed.) Medya Politikaları. Ankara: İmge Kitabevi.

Kili, S. (1981). Atatürk devrimi bir çağdaşlaşma modeli. Ankara: Türkiye İş Bankası.

Kongar, E. (2013). 21. yüzyılda Türkiye. İstanbul: Remzi Kitabevi.

Korkmaz, Z. (1981) Cumhuriyet devrinde yazı ve dil inkılabı. Milli Kültür, 3 (6).

Kurt, G. (2011). Televizyon dizilerinin iletişimsel ve dilbilimsel işlevleri. CIU Folklor/Edebiyat 17 (65)- 2001/1, 187-197.

Lewis, G. (1999). The Turkish language reform: A catastrophic success. Oxford: Oxford University Press.

McDermott, P. (2011). Migrant languages in the public space: A case study from Northern Ireland. Berlin, Münster, Vienna, Zurich and London: Lit Verlag.

Mete, M. (1992). Televizyon yayınlarının Türk toplumu üzerindeki etkisi. Ankara: Atatürk Kültür Merkezi Başkanlığı Yayınları.

Neydim, N. (2003). 80 sonrası paradigma değişimi açısından çeviri çocuk edebiyatı. İstanbul: Bu Yayınevi.

Noam, E. M. (2016). Who owns the world's media. New York: Oxford University Press.

Núñez, G. G. (2016). Translating in linguistically diverse societies: Translation policy in the United Kingdom. Amsterdam: John Benjamins Publishing Company.

Nye, J. S. (2017). Soft power: The means to success in world politics. (Rayhan İnan-Aydın Trans.). Yumuşak Güç. Ankara: BB101 Yayınları.

Okyayuz, Ş. \& Kaya, M. (2017). Görsel-işitsel çeviri eğitimi. Ankara: Siyasal Kitabevi. 
Okyayuz, Ş. (2017). From translation to originals... is it just a short step? New Writing: The International Journal for the Practice and Theory of Creative Writing, 14 (3), 348-368. DOI: http://dx.doi.org/10.1080/14790726.2017.1301961.

Okyayuz, Ş. (2017b). Power, Society and AVT in Turkey: an overview. In M. Deckert (Ed.), Audiovisual Translation and Use, (pp. 115-135). Lodz Studies in Language Series, Warsaw: Peter Lang.

Okyayuz, Ş. (2017c). Re-assessing the 'weight' of translations within the context of translated soap operas. Babel -Revue internationale de la traduction / International Journal of Translation, 63(5), 667-688. https://doi.org/10.1075/babel.00003.oky.

Orhan, S. (2017). Dil politikalari ve dil haklari üzerine teorik çerçeve. İnönü Üniversitesi Hukuk Fakültesi Dergisi, 8(2), 331-362.

Oskay, Ü. (1971). Toplumsal gelişmede radyo ve televizyon: Gerikalmışlık açısından olanaklar ve sınırlar. Ankara Üniversitesi Siyasal Bilgiler Fakültesi Yayınları No 316. Ankara: Sevinç Matbaasi.

Özerkan, Ş. (2012). Medya dil ve ideoloji. Illetişim Fakültesi dergisi 1 (2012), 63-76.

Özçağlayan, M. (1998). Yeni iletişim ve teknolojileri ve değişim. İstanbul:Alfa Yayınları.

Öztürk, Ş. (2004). Özel televizyon kanallarinin Türk haberciliğine etkisi. Selçuk İletişim, 3(2)- 2004, 97-112.

Paker, S. (Ed.). (2002). Translations: (Re)shaping of literature and culture. İstanbul: İstanbul Boğaziçi Press.

Pazarbaşı, B. (2016). Küresel eğlence endüstrisinde yaşanan gelişmenin televizyon programları ile dizi filmler üzerindeki etkileri. TRT Akademi, 01(01) -Ocak 2016, 170-187.

Plewa, B. (2002). Contrasting ethnic nationalism: Eastern cultural Europe. In S. Barbour \& C. Carmicheal (Ed.) Language and Nationalism, (pp183-220). Oxford: Oxford University Press.

RTÜK. (2019). Sağırların, işitme ve görme engellilerin medya hizmetlerine erişiminin iyileştirilmesi çalıştayı sonuç bildirgesi.Retrived on March 2019, from https://www.rtuk.gov.tr/assets/Galeri/Haberler/sagirlarinisitme-ve-gorme-engellilerin-gorsel-isitsel-medya-hizmetlerine-erisiminin-iyilestirilmesi-calistayi-sonuc-bildirisi.pdf.

Ruzza, B. (2002). Language and nationalism in Italy: Language as a weak marker of identity. In S. Barbour \& C. Carmicheal (Ed.) Language and Nationalism (pp.168-182). Oxford: Oxford University Press. S.168-182.

Sadoğlu, H. (2003). Türkiye'de ulusçuluk ve dil politikaları. İstanbul Bilgi Üniversitesi Yayınları.

Savaş, B. (2002) Kitle iletişim araçlarında argo kullanımı argoya toplumsal-dilbilimsel bir yaklaşım. In, E. Gürsoy Naskali, et al. Türk Kültüründe Argo, (pp. 349-360) The Netherlands: SOTA.

Scagnamillo, G. (2014). Türk sinema tarihi. İstanbul: Kabalc1 Yayınc1lık.

Simeoni, D. (1998). The pivotal status of the translator's habitus. Target,10(1), 1-39.

Spolsky, B. (2009). Language management. Cambridge: Cambridge University.

Şenyapı11, Ö. (1977). TV’nin Türk toplumuna etkileri. İstanbul: Milliyet Yayınları.

Tamer, E. C. (1983). Dünü ve bugünüyle televizyon. Istanbul: Varlık Yayınları.

Taşdelen, B. \& Kesim, M.. (2014). Etkileşimli televizyon geleneksel televizyona karşi:televizyon izleyicisi ne ister? Selçuk İletişim, 8 (3): 268-280. 
Tuna, K. (1991). Türk tarih tezleri ve sosyoloji. Tarih ve Sosyoloji Semineri 28-29 Mayıs 1990, İstanbul Üniversitesi Edebiyat Fakültesi Tarih Araştırma Merkezi, İstanbul: Edebiyat Fakültesi.

Tunç, A. (2005). Bir maniniz yoksa annemler size gelecek: 70'li yıllarda hayatımız. İstanbul: Can Yayınları.

Uçar, F. (2017). Türk siyasal hayatında iktidarların dil ve sanat politikalarına bir örnek: milliyetçi cephe hükümetleri dönemi. Asya Studies-Academic Social Studies/Akademik Sosyal Araştırmalar, 2 (Winter), 17-25.

Vikor, L. (2002). Northern Europe: Languages as prime markers of ethnic and national identity. In S. Barbour \& C. Carmicheal (Ed.). Language and Nationalism, (pp.105-129). Oxford: Oxford University Press.

Yıldız, A. (2001). Ne mutlu Türküm diyebilene Türk ulusal kimliğinin etno-seküler sinırları (19191938). İstanbul: İletişim.

\title{
Çeviri ve dil ve kültür politikaları: Görsel-işitsel çevirmen eğitiminde politik(a) artalan bilgisinin önemi
}

\begin{abstract}
$\ddot{O} \mathbf{z}$
Çeviri sürecinin ayrılmaz bir parçası olan dil ve kültür ile ilgili politikalar, çevirmenin işinin önemli bir parçasıdır. $\mathrm{Bu}$ nedenle de, çeviri eğitiminde, çeviri edimini şekillendiren politikalardan ve tarihsel bilgilerden günümüzde geçerli olan yönetmelik ve yaslara kadar, 'politik(a) artalan bilgisi' olarak adlandırılabilecek bilgiyi çeviri eğitimine dahil etmek gereklidir. Çalışmada, söz konusu hedef bağlamında görsel-işitsel çeviri dersleri kapsamında işlenebilecek bazı konulara değinilmeye çalışılmıştır. Amaç, işini çevreleyen politikayı bilen çevirmenler yetiştirmek için tasarlanan eğitimlerde kullanılabilecek belli eğitim bileşenlerini örneklemek ve gerekçelendirmektir. Devlet, dil politikaları ve çeviri arasındaki ilişkinin genel hatlarla ele alındığı bölümü takiben, üniversite düzeyinde çeviri eğitiminde görsel-işitsel çeviri dersleri kapsamına dahil edilebilecek eğitim bileşenleri önerilmektedir. Çalışma, görsel-işitsel çeviri alanında uzmanlaşmak isteyen çeviribilim eğitimcileri ve geleceğin çevirmenlerine ders içeriklerini zenginleştirmek için bazı öneriler sunmak ve bu konuda düşündürmek için kaleme alınmıştır.
\end{abstract}

Anahtar sözcükler: görsel-işitsel çeviri eğitimi; dil politikaları; dil ve kültür politikaları; çeviri; yumuşak güç

\section{AUTHOR BIODATA}

Assoc. Prof. Dr. Ayşe Şirin OKYAYUZ, is a trainer and researcher at the Bilkent University Department of Translation and Interpreting in Ankara - Turkey. She has published articles on audiovisual and literary translation and AVT training in academic journals, and contributed to international book chapters. She is the author of books on AVT practices and training in Turkey, a co-author of a book on AVT history, practice and training in Turkey, and also author to a book to which she contributes a chapter on her studies on remakes. In addition to her work as 
an audiovisual translator, she has translated children books, novels, short stories, drama for the stage, and books on politics and philosophy. She served as an advisory member of the Radio and Television Supreme Council negotiation meetings for the implementation of media accessibility practices in Turkey; she is a member of the Coordination Group which drafted the Turkish Translator and Interpreter National Proficiencies and Standard, and continues to work for the drafting of proficiencies for audiovisual translators. 